\title{
Front Matter: Volume 6555
}

, "Front Matter: Volume 6555," Proc. SPIE 6555, Sensors and Systems for Space Applications, 655501 (29 May 2007); doi: 10.1117/12.738964

SPIE Event: Defense and Security Symposium, 2007, Orlando, Florida, United SPIE. States 


\title{
PROCEEDINGS OF SPIE
}

\section{Sensors and Systems for Space Applications}

\author{
Richard T. Howard \\ Robert D. Richards \\ Editors
}

9-11 April 2007

Orlando, Florida, USA

Sponsored and Published by

SPIE-The International Society for Optical Engineering

Volume 6555

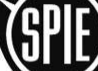

The International Society for Optical Engineering

Proceedings of SPIE-The International Society for Optical Engineering, 9780819466778, v. 6555

SPIE is an international technical society dedicated to advancing engineering and scientific applications of optical, photonic, imaging, electronic, and optoelectronic technologies. 
The papers included in this volume were part of the technical conference cited on the cover and title page. Papers were selected and subject to review by the editors and conference program committee. Some conference presentations may not be available for publication. The papers published in these proceedings reflect the work and thoughts of the authors and are published herein as submitted. The publisher is not responsible for the validity of the information or for any outcomes resulting from reliance thereon.

Please use the following format to cite material from this book:

Author(s), "Title of Paper," in Sensors and Systems for Space Applications, edited by Richard T. Howard, Robert D. Richards, Proceedings of SPIE Vol. 6555 (SPIE, Bellingham, WA, 2007) Article CID Number.

ISSN 0277-786X

ISBN 9780819466778

Published by

SPIE-The International Society for Optical Engineering

P.O. Box 10, Bellingham, Washington 98227-0010 USA

Telephone 1 360/676-3290 (Pacific Time) · Fax 1 360/647-1445

http://www.spie.org

Copyright (C) 2007, The Society of Photo-Optical Instrumentation Engineers

Copying of material in this book for internal or personal use, or for the internal or personal use of specific clients, beyond the fair use provisions granted by the U.S. Copyright Law is authorized by SPIE subject to payment of copying fees. The Transactional Reporting Service base fee for this volume is $\$ 18.00$ per article (or portion thereof), which should be paid directly to the Copyright Clearance Center (CCC), 222 Rosewood Drive, Danvers, MA 01923. Payment may also be made electronically through CCC Online at http://www.copyright.com. Other copying for republication, resale, advertising or promotion, or any form of systematic or multiple reproduction of any material in this book is prohibited except with permission in writing from the publisher. The CCC fee code is 0277 $786 \times / 07 / \$ 18.00$.

Printed in the United States of America. 


\section{Contents}

vii Conference Committee

ix Introduction

\section{SPACE TO GROUND SENSING}

655502 Remote sensing phase fluorimetry using mercury vapor lamp [6555-01]

M. A. Lundin, M. J. Bohn, Air Force Institute of Technology (USA)

655504 High-efficiency UV laser for space-based wind lidar [6555-03]

F. E. Hovis, Fibertek, Inc. (USA); J. Wang, Raytheon Space and Airborne Systems (USA)

655505 Space-based direct detection wind mission design [6555-04]

T. H. Zurbuchen, R. Walker, Univ. of Michigan (USA); C. Richey, J. Pavlich, P. Tchoryk, Jr., Michigan Aerospace Corp. (USA)

655506 Optical sensing of atmospheric emissions with Cubesats and Nanosats [6555-05]

G. Swenson, P. Thakker, F. Kamalabadi, M. Frank, V. Coverstone, Univ. of Illinois at Urbana-

Champaign (USA); H. Voss, Taylor Univ. (USA)

\section{CAMERA-BASED SENSING}

655507 Effects of optical artifacts in a laser-based spacecraft navigation sensor [6555-06]

J. E. LeCroy, D. S. Hallmark, The Boeing Co. (USA); R. T. Howard, NASA Marshall Space Flight Ctr. (USA)

655508 Super resolution structured light illumination [6555-07]

L. G. Hassebrook, A. G. Pethe, C. Casey, V. G. Yalla, D. L. Lau, Univ. of Kentucky (USA)

655509 Multicamera phase measuring profilometry for accurate depth measurement [6555-08]

Y. Wang, K. Liu, Q. Hao, D. Lau, L. G. Hassebrook, Univ. of Kentucky (USA)

Pagination: Proceedings of SPIE follow an e-First publication model, with papers published first online and then in print and on CD-ROM. Papers are published as they are submitted and meet publication criteria. A unique, consistent, permanent citation identifier (CID) number is assigned to each article at the time of the first publication. Utilization of CIDs allows articles to be fully citable as soon they are published online, and connects the same identifier to all online, print, and electronic versions of the publication.

SPIE uses a six-digit CID article numbering system in which:

- The first four digits correspond to the SPIE volume number.

- The last two digits indicate publication order within the volume using a Base 36 numbering system employing both numerals and letters. These two-number sets start with $00,01,02,03,04,05,06,07,08,09,0 A, 0 B \ldots$. OZ, followed by 10-1Z, 20-2Z, etc.

The CID number appears on each page of the manuscript. The complete citation is used on the first page, and an abbreviated version on subsequent pages. 
65550D Processing 3D flash LADAR point-clouds in real-time for flight applications [6555-12] R. Craig, I. Gravseth, R. P. Earhart, J. Bladt, S. Barnhill, L. Ruppert, C. Centamore, Ball Aerospace and Technologies Corp. (USA)

65550E Stereo-vision-based 3D modeling of space structures [6555-13]

S. Se, P. Jasiobedzki, MDA, Space Missions (Canada); R. Wildes, York Univ. (Canada)

$65550 \mathrm{~F}$ A pose and position measurement system for the Hubble Space Telescope servicing mission [6555-14]

M. Balch, D. Tandy, Advanced Optical Systems, Inc. (USA)

$65550 \mathrm{G}$ Simulation tests of a lidar-based spacecraft pose determination algorithm [6555-15]

R. C. Fenton, R. R. Fullmer, R. T. Pack, Utah State Univ. (USA)

\section{SENSORS AND SYSTEMS}

65550H Hydra AR\&D sensor suite [6555-16]

F. Roe, S. R. Granade, Advanced Optical Systems, Inc. (USA)

65550I The lunar orbiter laser altimeter (LOLA) on NASA's Lunar Reconnaissance Orbiter (LRO) mission [6555-17]

H. Riris, X. Sun, J. F. Cavanaugh, G. B. Jackson, L. Ramos-Izquierdo, D. E. Smith, NASA

Goddard Space Flight Ctr. (USA); M. Zuber, Massachusetts Institute of Technology (USA)

65550J Commissioning of the CALIPSO payload [6555-18]

C. Weimer, L. Ruppert, J. Spelman, Ball Aerospace and Technologies Corp. (USA)

65550K Utilizing UV and visible sensors on micro-satellites to demonstrate target acquisition and tracking [6555-19]

S. Brown, D. Wada, A. Ghafourian, M. Greenman, C. Harris, C. Howlett, T. Humpherys, Space Dynamics Lab., Utah State Univ. Research Foundation (USA); V. Nguyen, Missile Defense Agency (USA)

\section{SPACECRAFT SENSORS ANALYSIS AND RESULTS}

65550L DART AVGS flight results [6555-20]

R. T. Howard, T. C. Bryan, NASA Marshall Space Flight Ctr. (USA)

65550M Miniature, light weight, coherent optical receiver system for space platforms [6555-21]

A. Joshi, D. Becker, C. Wree, D. Mohr, Discovery Semiconductors, Inc. (USA)

$65550 \mathrm{~N}$ Real-world educational experience through project-oriented graduate classes in collaboration with industry [6555-22]

T. H. Zurbuchen, Univ. of Michigan (USA)

655500 High-resolution imaging with small satellites: what are the possibilities and limitations? [6555-23]

R. Sandau, German Aerospace Ctr. (Germany) 
65550P Autonomous docking experiments using the SPHERES testbed inside the ISS [6555-24]

S. Nolet, D. W. Miller, MIT Space Systems Lab. (USA)

PROPULSION SENSORS I

65550R Sensors and systems for space applications: A methodology for developing fault detection, diagnosis, and recovery [6555-26]

J. L. Edwards, R. M. Beekman, D. B. Buchanan, S. Farner, G. R. Gershzohn, M. Khuzadi,

D. F. Mikula, G. Nissen, J. Peck, S. Taylor, Boeing Co. (USA)

65550 Evaluation of holographic subsurface radar for NDE of space shuttle thermal protection tiles [6555-27]

T. LU, Jet Propulsion Lab. (USA); C. Snapp, NASA Johnson Space Ctr. (USA); T.-H. Chao,

A. Thakoor, Jet Propulsion Lab. (USA); T. Bechtel, Enviroscan, Inc. (USA) and Univ. of

Pennsylvania (USA); S. Ivashov, I. Vasiliev, Bauman Moscow State Technical Univ. (Russia)

PROPULSION SENSORS II

65550 Stable $600^{\circ} \mathrm{C}$ silicon carbide MEMS pressure transducers [6555-30]

R. S. Okojie, NASA Glenn Research Ctr. (USA)

SPACECRAFT PLATFORMS AND INFRASTRUCTURE

65550W Docking and reconfiguration of modular spacecraft: preliminary SWARM testing at MSFC [6555-32]

N. R. Hoff III, S. Mohan, S. Nolet, D. W. Miller, Massachusetts Institute of Technology (USA)

65550X Autonomous precision formation flying: a proposed fault tolerant attitude control strategy [6555-33]

T. Jiang, K. Khorasani, Concordia Univ. (Canada)

65550Y SUMO/FREND: vision system for autonomous satellite grapple [6555-35]

J. Obermark, DCS Corp. (USA); G. Creamer, B. E. Kelm, Naval Research Lab. (USA);

W. Wagner, Honeywell Technical Solutions, Inc. (USA); C. G. Henshaw, Naval Research Lab. (USA)

\section{OPTICAL MODELING AND TESTING}

$65550 Z$ Quantifying an imagery system's performance with transformational mission data analysis [6555-36]

A. W. Mauck, Booz Allen Hamilton Inc. (USA)

655510 Modeling of electro-statically actuated two-axis (tip-tilt) MEMS torsion micro-mirrors for laser beamsteering [6555-38]

C. L. Edwards, B. G. Boone, Johns Hopkins Univ. Applied Physics Lab. (USA); W. S. Levine,

C. C. Davis, Univ. of Maryland, College Park (USA) 
655511 A low-cost test-bed for real-time landmark tracking [6555-39]

A. Csaszar, California Institute of Technology (USA); J. C. Hanan, Oklahoma State Univ. (USA); P. Moreels, California Institute of Technology (USA); C. Assad, Jet Propulsion Lab. (USA)

655512 Automated rendezvous and docking sensor testing at the flight robotics laboratory [6555-40]

R. T. Howard, M. L. Williamson, A. S. Johnston, L. L. Brewster, NASA Marshall Space Flight Ctr. (USA); J. D. Mitchell, S. P. Cryan, NASA Johnson Space Ctr. (USA); D. Strack, Odyssey Space Research, LLC (USA); K. Key, L3 Communications (USA)

655513 New approach to analysis and new principles for optimization of remote sensing systems [6555-41]

A. H. Hamid, H. A. Tariyel, K. M. Jalal, I. A. Azad, Azerbaijan National Aerospace Agency (Azerbaijan)

\section{SPACECRAFT MODELING AND CONTROL}

655514 Optimal design of systems that evolve over time using neural networks [6555-42]

M. K. Nolan, Massachusetts Institute of Technology (USA)

655515 Modeling and control of active gravity off-loading for deployable space structures [6555-43]

T. J. Bihl, Ohio Univ. (USA); K. D. Pham, T. W. Murphey, Air Force Research Lab. (USA)

655518 The differential game barrier model for spacecraft under target maneuvering based on minimum error [6555-46]

Q. Zhang, J. Chen, S. Sun, Y. Sun, Harbin Institute of Technology (China)

\section{SIMULATION, ROBOTICS, AND TESTING}

655519 Simulation study of a robotics-based method for on-orbit identification of spacecraft inertia properties [6555-47]

O. Ma, H. Dang, New Mexico State Univ. (USA); K. Pham, Air Force Research Lab. (USA)

$65551 \mathrm{~A}$ Online tribology ball bearing fault detection and identification [6555-48]

B. Ling, Migma Systems, Inc. (USA); M. M. Khonsari, Louisiana State Univ. (USA)

Author Index 


\title{
Conference Committee
}

\author{
Symposium Chair
}

John C. Carrano, Luminex Corporation (USA)

Symposium Cochair

Larry B. Stotts, Defense Advanced Research Projects Agency (USA)

Program Track Chairs

Peter Tchoryk, Jr., Michigan Aerospace Corporation (USA)

Roger Hall, Advanced Research Projects Agency (USA)

Conference Chairs

Richard T. Howard, NASA Marshall Space Flight Center (USA)

Robert D. Richards, Optech, Inc. (Canada)

Program Committee

Michael T. Dehring, Michigan Aerospace Corporation (USA)

Olivier L. de Weck, Massachusetts Institute of Technology (USA)

Michael E. Dobbs, ITT Industries, Inc. (USA)

Stephen R. Granade, Advanced Optical Systems, Inc. (USA)

Shahid Habib, NASA Goddard Space Flight Center (USA)

Carl G. Henshaw, Naval Research Laboratory (USA)

Brian Holz, Ball Aerospace and Technologies Corporation (USA)

Floyd E. Hovis, Fibertek, Inc. (USA)

Daniel L. Lau, University of Kentucky (USA)

Pejmun Motaghedi, The Boeing Company (USA)

\section{Session Chairs}

1 Space to Ground Sensing

Richard T. Howard, NASA Marshall Space Flight Center (USA)

Robert D. Richards, Optech, Inc. (Canada)

2 Camera-Based Sensing

Floyd E. Hovis, Fibertek, Inc. (USA)

Michael E. Dobbs, ITT Industries, Inc. (USA)

3 Three-Dimensional Position and Attitude Sensing

Richard T. Howard, NASA Marshall Space Flight Center (USA)

Robert D. Richards, Optech, Inc. (Canada) 
Richard T. Howard, NASA Marshall Space Flight Center (USA)

Robert D. Richards, Optech, Inc. (Canada)

$5 \quad$ Spacecraft Sensors Analysis and Results

Richard T. Howard, NASA Marshall Space Flight Center (USA)

Robert D. Richards, Optech, Inc. (Canada)

Stephen R. Granade, Advanced Optical Systems, Inc. (USA)

6 Keynote Session

Richard T. Howard, NASA Marshall Space Flight Center (USA)

Robert D. Richards, Optech, Inc. (Canada)

7 Propulsion Sensors I

Valentin Korman, Madison Research Corporation (USA)

8 Propulsion Sensors II

Valentin Korman, Madison Research Corporation (USA)

9 Spacecraft Platforms and Infrastructure

Charles J. Finley, Air Force Research Laboratory (USA)

Richard T. Howard, NASA Marshall Space Flight Center (USA)

10 Optical Modeling and Testing

Pejmun Motaghedi, The Boeing Company (USA)

Deborah J. Howell, Massachusetts Institute of Technology (USA)

11 Spacecraft Modeling and Control

Pejmun Motaghedi, The Boeing Company (USA)

Deborah J. Howell, Massachusetts Institute of Technology (USA)

12 Simulation, Robotics, and Testing

Pejmun Motaghedi, The Boeing Company (USA)

Deborah J. Howell, Massachusetts Institute of Technology (USA) 


\section{Introduction}

This was to be the fourth year of the Spaceborne Sensors conference, and it was the fourth year for that conference and more. The Sensors and Systems for Space Technologies conference included Spaceborne Sensors, Propulsion Sensors, Spacecraft Platforms and Infrastructure, and Modeling, Simulation, and Verification of Space-based Systems. As part of the Space Technologies and Operations Track at the 2007 Defense and Security Symposium, the Sensors and Systems for Space Technologies conference covered important parts of any space operation: How do you model your sensors and systems? How do you verify and test them? How well do they work on orbit? This year's conference answered those questions in a variety of ways.

The keynote speaker this year was Mr. Bob Friend of The Boeing Co. (who just won their 2006 Engineer of the Year award!). He is the Project Manager and Chief Engineer of the Orbital Express project; a project that launched two satellites in orbit in March, 2007 and is scheduled to operate until June, 2007. His talk was entitled "Orbital Express: Mission Status and Goals." The talk was about the Orbital Express mission, which combines experiments testing all of the different capabilities that a satellite servicing system might need: fluid transfer, orbital replacement unit transfer (such as batteries and computers), and sensors for automated rendezvous and docking. These technologies have been in development and testing on the ground for years, but this was the first United States experiment to put them all together on orbit.

Overall, there are 36 papers in these proceedings, covering sensors, systems, methodologies, and technologies ranging from individual components all the way up to full operational sensors and systems as well as laboratory work in sensor analysis and theoretical research.

Many of the theoretical and laboratory technologies presented in previous years were back this year with updates and improvements, and it has been very nice to see the progress of sensors, systems, and technologies over the years this conference has been in place; several items first presented two or three years ago have now been flown in space. Space operations are key to the future of people and countries, both in defense and in expanding the use of space for civil purposes. The Sensors and Systems for Space Technologies conference contributes to the future by getting professionals together to hear one another's approaches to problems and allowing technologists to discuss innovative ideas.

We want to thank all of the authors for their time and energy in getting papers and presentations to the conference, and we want to thank the program committee for their efforts in encouraging authors. Without your hard work, this conference would not have been a success. In addition, we would like to thank 
SPIE for supporting the Space Technologies Track and for all their assistance in bringing everything together. Finally, thank you to all of you who attended the sessions, asked interesting questions, and prompted further discussions both during and after the sessions.

Richard T. Howard Robert D. Richards 